\title{
Immunotherapy with natural killer cells: a possible approach for the treatment of Acute Myeloid Leukemia also in Brazil
}

\author{
LÚCIA SILLA, MD, PHD ${ }^{1 *}$ \\ ${ }^{1}$ Full Professor at Faculdade de Medicina da Universidade Federal do Rio Grande do Sul - UFRGS. Head of the Technology and Cell Therapy Center of Hospital de Clínicas of Porto Alegre - HCPA, Porto Alegre - RS
}

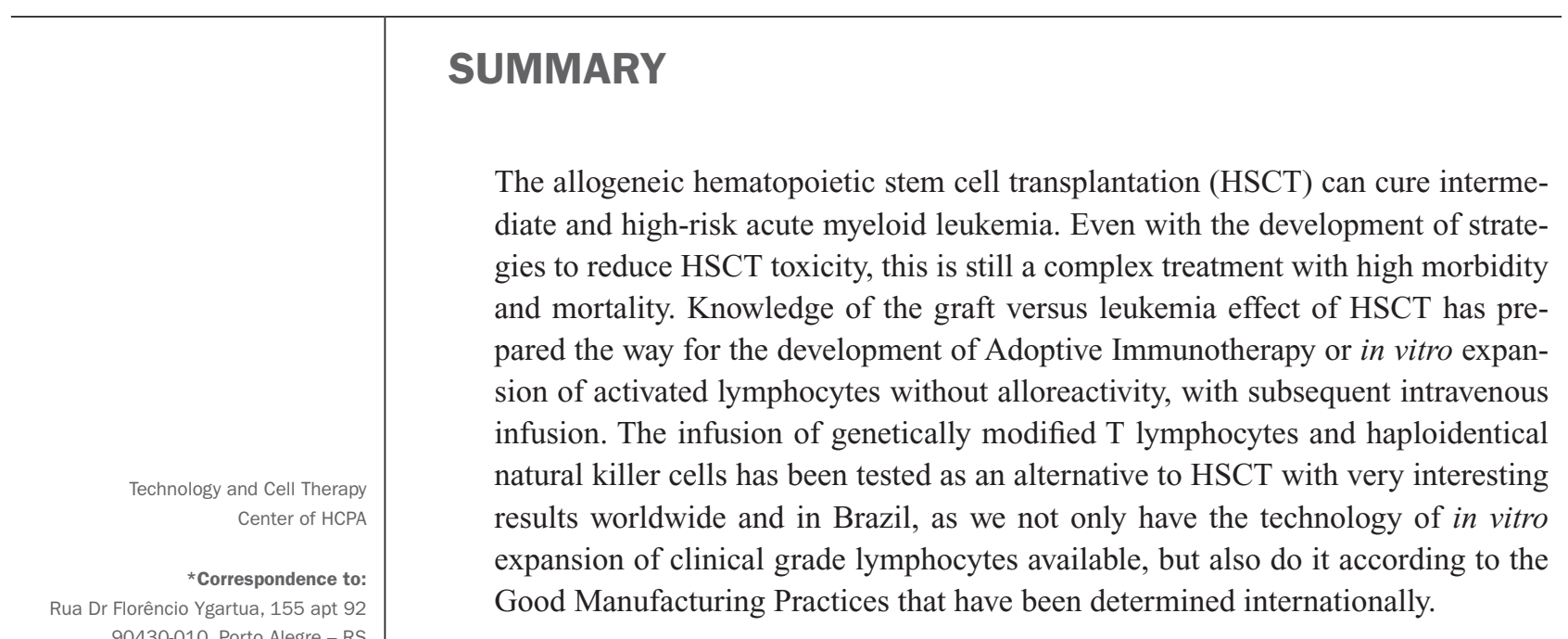

Keywords: NK cells, graft versus leukemia effect, adoptive immunotherapy, acute myeloid leukemia.

The Hematopoietic Stem Cell Transplantation (HSCT) is currently the curative option for intermediate and high-risk acute myeloid leukemia (AML); procedure toxicity and complexity can, however, result in a series of harmful consequences for the body even when cured of the malignancy. Since the beginning of the 1990s, it has been known that the curative action of HSCT depends on the effect of graft immune cells on residual malignant disease - the graft-versusleukemia effect - consolidating the knowledge of the immune system role in eradicating malignancy ${ }^{1}$.

Immunotherapy based on the use of activated immune cells, also known as Adoptive Immunotherapy (AI), aims to use the patient's own immune cells or those of a selected donor, in order to eradicate the malignant disease without the risk of graft-versus-host-disease (GVHD) development observed in the HSCT scenario. The results of AI, tested initially and for many years in the treatment of solid cancers, particularly melanoma, have become consistent after Rosenberg ${ }^{2}$ demonstrated that it is essential to eliminate or attenuate the activity of the patient's immune cells prior to the lymphocyte infusion, as to allow the ex-vivo activated lymphocytes, when infused, to find an environment rich in growth factors and thus proliferate and perform their antitumor action markedly and continuously.
The recent development of T-lymphocytes modified by inserting Chimeric Antigen Receptors (CAR) into them and their infusion after the patient's immune system ablation demonstrates the principle that $\mathrm{AI}$ is a promising treatment ${ }^{3}$. However, the infusion of CAR lymphocytes, with significant antitumor activity, it followed by tumor lysis syndrome that results in a cytokine storm, of which the patient, if not adequately treated with specific immunological blockers, may die. Fortunately, these are preliminary results obtained in the treatment of patients with significant tumor mass. Perhaps the use of immune effectors in a residual tumor disease scenario might minimize these effects and thus, phase II studies including patients in complete remission of the disease are needed to test this hypothesis.

In the treatment of AML, particularly when using the haploidentical HSCT, the role of natural killer (NK) cells in eradicating the disease dissociated from GVHD was demonstrated $^{4}$. Therefore, NK cells seem to be natural candidates for $\mathrm{AI}$ in the treatment of this disease and their infusion, without HSCT, in patients with AML, has shown to be effectives.

The great challenge has been, however, to achieve the in vitro expansion of a population of purified NK cells, with no contamination by $\mathrm{T}$ lymphocytes - a very difficult 
task, because NK cells are relatively rare in peripheral blood. The development of cells with artificial antigens that received the insertion of adhesion molecules and specific cytokines, when co-cultured with mononuclear cells previously depleted of $\mathrm{T}$ lymphocytes, has been shown to be a promising technique to obtain up to 1010 NK cells with purity levels $>90 \%{ }^{6}$.

This technology is established in Brazil, more precisely in the Technology and Cell Therapy Center of Porto Alegre University Hospital. A clinical trial about the safety and feasibility of AI with expanded NK cells for the treatment of recurrent or treatment-refractory AML has already been approved in Brazil and ongoing at MD Anderson Cancer Center (MDACC), in Houston, TX, USA. The first three patients that have already treated in Houston have shown that not only the infusion of these cells is not accompanied by any adverse effects, but also that the answer seems to be slow and gradual, as four months after treatment the disease residual levels remain decreased, demonstrating not only the antitumor action of these cells but also the permanence of these cells or their effect for a prolonged period. The inclusion of the first patient treated in Brazil should take place within a few weeks. In a review recently published by our group ${ }^{7}$ it is possible to have a broader and more comprehensive view of the role of NK cells in the treatment of neoplasms.

\section{Resumo}

Imunoterapia com células natural killer: um caminho possível para o tratamento da Leucemia Mielóide Aguda também no Brasil
$\mathrm{O}$ transplante de células-tronco hematopoéticas (TCTH) alogênico é curativo para leucemia mielóide aguda de risco intermediário e alto. Mesmo com o desenvolvimento de estratégias para minorar a toxicidade do TCTH, este ainda é um tratamento complexo com elevada morbi-mortalidade. O conhecimento sobre o efeito enxerto contra leukemia do TCTH pavimentou o caminho para o desenvolvimento da Imunoterapia Adotiva ou expansão in vitro de linfócitos ativados, sem alo-reatividade, com posterior infusão endovenosa. A infusão de Linfócitos T geneticamente modificados e de células Natural Killer haploidenticas tem sido testada como alternativa ao TCTH com resultados bastante interessantes no mundo e no Brazil já que não apenas dominamos a tecnologia de expansão in vitro de linfócitos em grau clínico, como o fazemos segundo as Boas Práticas de Manufatura determinadas internacionalmente.

Palavras-chave: Células NK, efeito enxerto contra leucemia, imunoterapia adotiva, leukemia mieloide aguda.

\section{References}

1. Barrett AJ. Understanding and harnessing the graft-versus-leukaemia effect. Br. J. Haematol. 2008;142:877-88.

2. Dudley ME, Wunderlich JR, Yang JC, Sherry RM, Topalian SL, Restifo NP, et al. Adoptive cell transfer therapy following non-myeloablative but lymphodepleting chemotherapy for the treatment of patients with refractory metastatic melanoma. J Clin Oncol. 2005;23:2346-57.

3. Aplenc R, Porter DL, Rheingold SR, Teachey DT, Chew A, Hauck B, et al. Chimeric antigen receptor-modified $\mathrm{T}$ cells for acute lymphoid leukemia. $\mathrm{N}$ Engl J Med. 2013;368:1509-18.

4. Ruggeri L, Capanni M, Urbani E, Perruccio K, Shlomchik WD, Tosti A, et al Effectiveness of donor natural killer cell alloreactivity in mismatched hematopoietic transplants. Science. 2002;295:2097-100.

5. Miller JS, Soignier Y, Panoskaltsis-Mortari A, McNearney SA, Yun GH, Fautsch SK, et al. Successful adoptive transfer and in vivo expansion of human haploidentical NK cells in patients with cancer. Blood. 2005;105:3051-7.

6. Denman CJ, Senyukov VV, Somanchi SS, Phatarpekar PV, Kopp LM, Johnson $\mathrm{JL}$, et al. Membrane-bound IL-21 promotes sustained ex vivo proliferation of human natural killer cells. PLoS One. 7;2012:e30264

7. Baggio L, Laureano AM, Silla LMR, Lee DA. Natural killer cell adoptive immunotherapy: Coming of age. Clin. Immunol. 2016;pii:S1521-6616(16)30019-5.8. 